\title{
THE ANALYSIS OF PISA TEST 2018 ON STUDENT PERCEPTION OF READING OBJECTIVE, HOW IS INDONESIAN STUDENTS?
}

\author{
Safari Safari, Asrijanty Asrijanty, Rahmawati Rahmawati and Bagus Hary Prakoso \\ Center for Assessment and Learning, Ministry of Education and Culture \\ Jl. Gunung Sahari Raya No. 4, Jakarta, 10710, Indonesia
}

\begin{abstract}
The purposes of the study are to know the students' perceptions of reading objective among students, which have above and below the average score of the OECD countries, and to know the Indonesian'student achievement among other countries. The study uses a quantitative method as a research method, and to determine the position of Indonesian students, it used M-Plus and Winsteps program. PISA 2018 data which has been released are used for research development purposes. The data were taken from questionnaires who were answered by $15^{\text {th }}$-year-students of 80 countries. The data consist of 612.004 international students and 12.098 Indonesian students. The results of the Analysis of Variance states that there was a significant difference $(\mathrm{P}<0,000)$ of students' perceptions of reading objectives among students in countries which have above and below the average score of the OECD. While based on the analysis of Rasch Model, the reliability of Indonesian students was 0.36 while international data 0.51 . Although they both are low, the reliability of Indonesian students is lower. The study concludes that the most students' states both (upper and below group) "Disagree" if the purpose of reading is only to fulfill obligations, merely hobbies, and spend time. Afterwards, students state "Agree" to discuss books with others and obtain the required information.
\end{abstract}

\section{KEYWORDS}

Perception, Students, Reading Objective, PISA

\section{INTRODUCTION}

Literacy problems in assessing Indonesian education can refer to the results of the Program for International Student Assessment (PISA). The science and mathematics literacy index of Indonesian students increased significantly by 21 and 11 points respectively: 382 points in 2012 to 403 in 2015, and 375 points in 2012 and 386 in 2015. Meanwhile, the reading literacy index only increased by one points: 396 in 2012, 397 in 2015, and dropped to 371 in 2018 (ranked 72nd out of 78 countries). Therefore, this study focuses only on the position of Indonesia.

This achievement dissatisfaction occurs due to several reasons related to test content, student competence, computer-based models, and learning models that do not encourage exploratory reading strategies (Kompas News, 2017). Other findings support the importance of reading habits for academic achievement (Owusu-Acheaw \& Larson, 2014), Wan Dollah et al. (2017). To identify reading habits, certain investigations are needed, such as how students perceive reading goals in the PISA test. Guay et al. (2010) found that girls have higher intrinsic motivation to read and write than boys. The results of this study are the same as the research results of other experts. Reardon, et al. (2018) conducted research on gender disparities in United States school districts and reported that gender attainment gaps exist among school districts. Sindik (2011) conducted a study on gender differences in the use of learning strategies for adult foreign language learners at the American Academy of Management and Technology. This study reported significant gender differences in the use of learning strategies. Fergusson and Horwood (1997) study of gender differences in educational achievement in the New Zealand birth cohort reported statistically significant gender differences in academic achievement. Igbudu (2015) conducted a study on the influence of gender on student academic achievement in government subjects in public high school schools in the Oredo Regional Government area of 
Edo State. All of these studies show that there is a significant gender difference in academic achievement, namely that women perform better than men.

In the PISA questionnaire 2018, questions related to the reading objective are code ST160 (ST160Q011A, ST160Q021A, ST160Q031A, ST160Q041A, and ST160Q051. How much do you agree or disagree with the statement about the objective of reading e.g.: (1) reading only for obligations, (2) is a favorite / hobby, (3) discussing books with others, (4) just wasting time, (5) to obtain the required information. Actually the reading objectives are more than five. In PISA 2018, it focuses on those five objectives only. According to Grabe (2009), there are 9 objectives of reading, namely: reading to find information, reading for rapid understanding, reading to learn, reading to integrate information, reading to evaluate, criticizing and using information, and reading for general understanding, cases, reading for interest or reading to entertain.

The reading objective is "the intention to combine complex processes" (Grabe, 2004, p. 14), which combines understanding: text, parts, paragraphs even books and the ability to understand and find out information presented in written text (Nasri \& Namaziandost, 2019). The understanding of reading between students is different due to the different process ... (Brantmeier, 2005). Every student has different goals in reading activities. This goal is important because it is closely related to the level of completeness of student competencies that must be possessed by each student. The level of completeness of competencies (knowledge, skills, and attitudes) can mostly only be obtained through reading activities. The results of Par's study (2020) showed there was a significant correlation between overall use of reading strategies and student reading achievement. The more students apply problem solving strategies in reading activities, the better their ability to understand texts. Therefore, this study only focuses on the variable students' reading objectives which were asked in the 2018 PISA test questionnaire.

Abidin (2017: 56) argues that reading was very helpful for students to obtain or meet their needs in the form of knowledge, information, experience, skills, and so on. Talwiasih (2019: 61) suggests that reading was an activity or cognitive process that seeks to find various information contained in writing. Putra, Purwadi, and Wulandari (2017: 234) explained that reading was a language skill that is related to other language skills. But the main object of the purpose of reading is the book. Books were a storehouse of knowledge, reading was the key, (Tosepu, 2018). Most curricula in schools do not provide sufficient time to develop reading skills, (Grabe, 2002). Its implementation in classroom learning must use a strategy of "reading efficiency" (Lin, 2008, 2009b). The efficiency of reading depends on the strategies and the reading method models used.

Parents of students and teachers in schools were the main supporters of students in providing motivation to read. Pachtman and Wilson (2006) stated that it was very important to motivate students to read by giving them the opportunity to choose their material of interest because one of the most important factors that helps learners read further was reading motivation and has an important impact on reading comprehension (Hairul, Ahmadi , and Pourhosein, 2012). According to Guthrie and Wigfield (2000), reading motivation was the great enthusiasm of students in learning who must consider positive or negative ideas about reading.

Referring the various descriptions, the study focuses on whether there are differences on perception of reading objective between students come from countries with above and below the average score of the PISA 2018 test.

\section{RESEARCH METHOD}

The method used is quantitative method. The basis for using this method is adjusted to the main purpose of this study, namely obtaining facts from existing symptoms and factually finding facts based on research data. This research uses PISA 2018 data that has been released to the public and has been permitted. The study population was 15 year old students taking the 2018 study, while the sample was 15 year old students who took PISA tests in 80 countries. The reason for choosing the sample was students who took the PISA test in 2018.

The data used is in the form of a questionnaire with four choices (strongly disagree, disagree, agree, and strongly agree) which were answered by 6,124 students from 80 countries, and answered by 1,2098 Indonesian students. The questions in the questionnaire related to the purpose of reading are (1) obligations, (2) hobbies / interests, (3) like talking about other people's books, (4) wasting time, (5) just to get the information needed. 
There were 22 countries on PISA test results for reading tests have above an average score of the OECD (487) are: Canada, Switzerland, Czech Republic, Germany, Denmark, Estonia, Finland, France, United Kingdom, Hong Kong, Ireland, Japan, Korea, Macao, Norway, New Zealand, Poland, Portugal, BSJZ (China), Singapore, Sweden, Chinese Taipei, and the United States. While the countries with below the average score of the OECD are 58 countries: Albania, United Arab Emirates, Argentina, Austria, Belgium, Bulgaria, Bosnia and Herzegovina, Belarus, Brazil, Brunei Darussalam, Chile, Colombia, Costa Rica, Dominican Republic, Spain, Georgia, Greece, Croatia, Hungary, Indonesia, Iceland, Islael, Italy, Jordan, Kazakhstan, Kosovo, Lebanon, Lithuania, Luxembourg, Latvia, Morocco, Moldova, Mexico, North Macedonia, Malta, Montenegro, Malaysia, Netherlands, Panama, Peru, Philippines, Qatar, Azerbaijan, Moscow Region, Tatarstan, Romania, Russian Federation, Saudi Arabia, Serbia, Slovak Republic, Slovenia, Thailand, Turkey, Ukraine, Uruguay and Vietnam (Gurria, Secretary General OECD, 2019).

The analytical method used in this research is analysis of variance. This analysis is used to calculate differences in the perceptions of students, both women and men, on all reading objective between the countries with have above and below average score of the OECD. So that the results of the analysis of this study can be obtained accurately, then all data in this study are processed or analyzed using the SPSS 22.00 program. In addition, to determine the position of Indonesian students, the data were analyzed by using M-Plus and Winsteps Programs.

\section{RESEARCH RESULT}

Here are the percentage of students (612.004 people) from 80 countries who have filled out the PISA questionnaire.

Table 1. Percentage of Students on Reading Objective Both Groups (above and below group)

\begin{tabular}{|c|l|c|c|c|c|c|c|c|c|c|c|}
\hline N & Aspect & \multicolumn{2}{|c|}{$\begin{array}{c}\text { I read only if I } \\
\text { have to }\end{array}$} & \multicolumn{2}{|c|}{$\begin{array}{c}\text { My favourite } \\
\text { hobbies }\end{array}$} & \multicolumn{2}{|c|}{$\begin{array}{c}\text { Talking about } \\
\text { books with other } \\
\text { people }\end{array}$} & \multicolumn{2}{|c|}{$\begin{array}{c}\text { Reading is a } \\
\text { waste of time }\end{array}$} & \multicolumn{2}{|c|}{$\begin{array}{c}\text { Get information that } \\
\text { I need }\end{array}$} \\
\cline { 3 - 13 } & & $\mathrm{F}$ & $\%$ & $\mathrm{~F}$ & $\%$ & $\mathrm{~F}$ & $\%$ & $\mathrm{~F}$ & $\%$ & $\mathrm{~F}$ & $\%$ \\
\hline 1. & $\begin{array}{l}\text { Strongly } \\
\text { disagree }\end{array}$ & 129886 & 21,2 & 124665 & 20,4 & 125491 & 20,5 & 211385 & 34,5 & 97585 & 15,9 \\
\hline 2. & Disagree & 186853 & 30,5 & 183939 & 30,1 & 183241 & 29,9 & 227256 & 37,1 & 181240 & 29,6 \\
\hline 3. & Agree & 173651 & 28,4 & 180841 & 29,5 & 191778 & 31,3 & 86087 & 14,1 & 206311 & 33,7 \\
\hline 4. & $\begin{array}{l}\text { Strongly } \\
\text { agree }\end{array}$ & 83841 & 13,7 & 81307 & 13,3 & 68932 & 11,3 & 46280 & 7,6 & 87113 & 14,2 \\
\hline
\end{tabular}

Table 1 informs that most students state "Disagree" if the purpose of reading is only to: (1) fulfill obligations, (2) merely hobbies, (3) spend time, but most students' state "Agree" to: (1) discuss books with people others and (2) obtain the required information. However, statements of students who are in countries above the OECD average (insufficient data shown here), most stated "Agree" if the purpose of reading to: (1) fulfill obligations, (2) channel hobbies, (3) discuss books with other people, (4) spending time, and (5) obtaining the information needed. Statements of students who are in the countries below the OECD average, most say "Agree" if the purpose of reading is to: (1) hobbies, (2) discuss books with others, and (3) get the necessary information, but most students state "Disagree" to: (1) fulfill obligations and (2) spend time.

Table 2. Results of Analysis of Variance on Students' Reading Objectives Differences in Countries Above and Below the OECD Average Value

\begin{tabular}{|c|l|c|c|c|c|c|}
\hline No. & \multicolumn{1}{|c|}{ Source } & $\begin{array}{c}\text { Type III Sum } \\
\text { of Squares }\end{array}$ & df & Mean Square & F & Sig. \\
\hline 1. & I read only if I have to & 952,258 & 1 & 952,258 & 976,300 &, 000 \\
\hline 2. & My favourite hobbies & 5077,764 & 1 & 5077,764 & 5349,222 &, 000 \\
\hline 3. & $\begin{array}{l}\text { Talking about books with } \\
\text { other people }\end{array}$ & 4022,488 & 1 & 4022,488 & 4440,938 &, 000 \\
\hline 4. & Reading is a waste of time & 1793,262 & 1 & 1793,262 & 2138,060 &, 000 \\
\hline 5. & Get information that I need & 617,904 & 1 & 617,904 & 690,852 &, 000 \\
\hline
\end{tabular}


Table 2 informs that based on the results of the analysis of variance shows that there are differences in the perceptions of students to reading objective between the countries above and below the average score of the OECD $(\mathrm{P}<0.05)$.

\section{DISCUSSION}

The results showed that the difference in students' perceptions of reading goals between countries that had a mean score above and below the OECD was evident $(\mathrm{P}<0.05)$. Most students stated "Disagree" if the purpose of reading was only to: (1) fulfill an obligation, (2) just a hobby, (3) spend time, but most students stated "Agree" to: (1) discuss books with other people and (2) obtain the necessary information. Let's take a look at the following examples of Indonesian students analyzed with Mplus. The main objective is to determine the relationship between variables in this study.

Figure 1 is PISA 2018 data for Indonesian students analyzed by the Mplus program version 8.2 which aims to determine the position of Indonesian students.

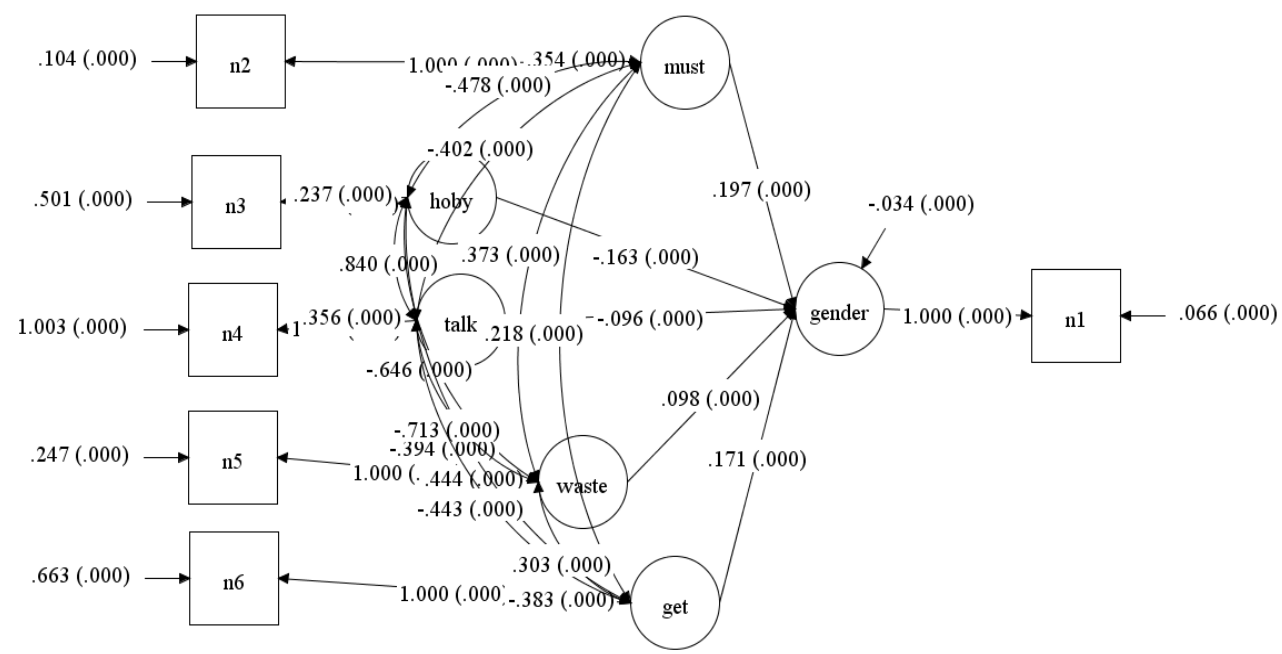

Figure 1. Relationship between Reading Objective and Gender (Indonesian Students)

Based on Figure 1, the reading objectives of Indonesian students (male and female) start from the smallest because: (1) a hobby or hobby (hobby) with a loading factor of -0.163 ; (2) discussing other people's books (talk) with a loading factor of -0.096; (3) lazy to read books because they spend time (wasteful) with a loading factor of 0.098 ; (4) reading only looking for the information needed to lead (get) with a loading factor of 0.171 ; (5) reading due to obligation (must) with a loading factor of 0.197 . To determine the reliability of items and people from the perception data of international and Indonesian students, they were analyzed using the Rasch Model (see Table 3 and Table 4).

Table 3. Results of Rasch Model Analysis on Indonesian Student Data

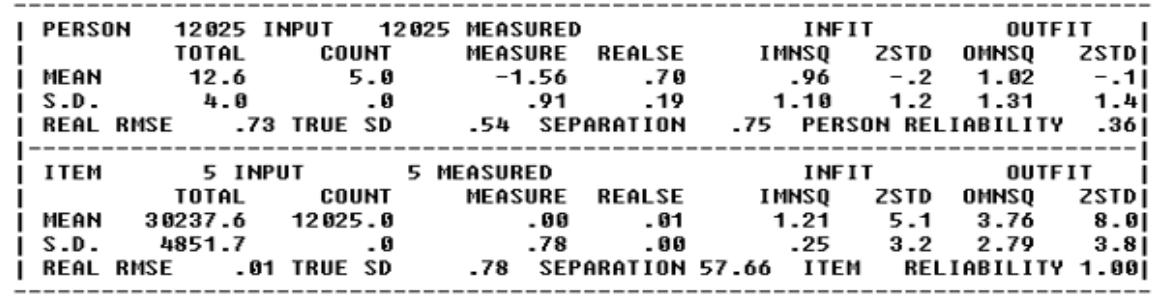


Table 4. Results of Rasch Model Analysis in International Data

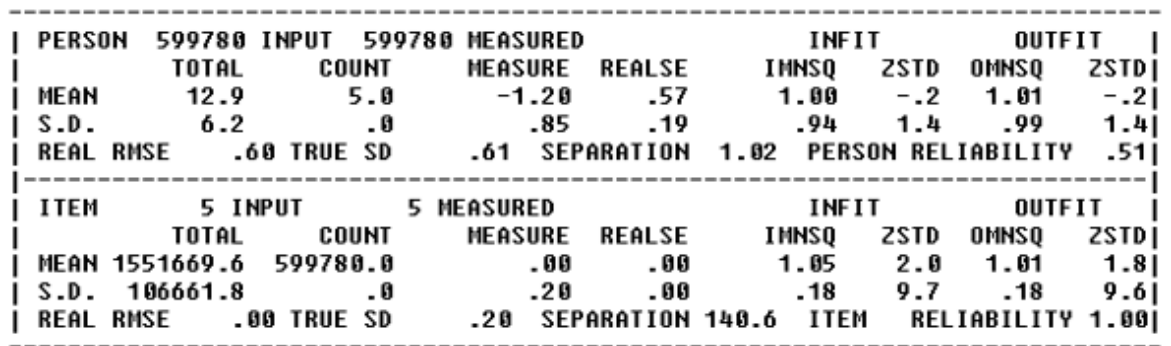

Refering to Table 3 and Table 4, the reliability of Indonesian students is 0.36 , and international students is 0.51 . Although both are low, the reliability of Indonesian students is lower. Based on the two results of this analysis, there were students who have reading objective were only to fulfill obligations. Although most of the students (30.5\%) expressed disagreement and $21.2 \%$ stated strongly disagree, however the second most statement that were $28.4 \%$ of students stated agree and $13.7 \%$ students stated strongly agree. There were two groups here who agree. This means that this group agrees that the reading objective is to fulfill obligations. The second group stated that they did not agree if the reading objective was only to fulfill obligations. Both should be to fulfill the obligation or not that the reading objective takes precedence.

It shows that most students have begun to realize that reading objective is not just to fulfill obligations such as reading assigned by the teacher at school but for personal or individual needs. It could be students who agree and strongly agree because at school they rarely get an explanation from their teacher, so interest in reading is still limited or depends on the assignment at school. This is in accordance with Rohman (2017) research results that the lack of independence of reading students, in learning at school because teachers rarely foster the interest in reading in children and the obstacles that are often faced in learning in children.

The results of Par's study (2020) also stated emphatically that most students rarely read because the majority of them spend less than 2 hours each day for reading. They were content to read only when were given an assignment or when an exam was near. Students were not given a problem solving strategy in reading so many students were incomplete in reading. The more students who applied problem solving strategies in reading activities, the better their ability to understand texts. So, in order to be successful in learning, students must read widely and apply effective reading strategies to construct the meaning of texts, (Denton et al., 2015).

Such conditions will affect other reading goals, such as reading purposes only for pleasure / hobbies. Even though most of the students (30.1\%) and (20.4\%) stated that they disagreed and strongly disagreed, many students $(29.5 \%)$ and $(13.3 \%)$ who agreed and strongly agreed. Another example is the purpose of reading to discuss books that are read with others. Although most students $(31.3 \%)$ and $(11.3 \%)$ agreed and strongly agreed, many students (29.9\%) and $20.5 \%)$ stated that they did not agree and strongly disagreed. There were also students who have the notion that reading activities only consume time. Most students $(37.1 \%)$ and $(34.5 \%)$ expressed disagreement and strongly disagree, but many students $(14.1 \%)$ and $(7.6 \%)$ stated agreed and strongly agreed. In general, the reading objective was only to obtain important information. Although most of the students (33.7\%) and (14.2\%) agreed and strongly agreed, many students (29.6\%) and (15.9\%) stated that they did not agree and strongly disagreed.

What's more with the continued development of technology. Students also really need guidance in reading strategies with computers because the exams are now all computer based. Although the research of Mangen et al. (2020) shows that students who have read text in printed form were significantly better at reading comprehension tests than students who read text digitally (Mangen, et al., 2020). Many students were slower when reading from a screen than from paper (Muter et al., 1982; Mayes, Sims, \& Koonce, 2001). But current technological developments show that the digital revolution has greatly influenced daily life. Proven in the existence of mobile devices and seamless integration of technology into general tasks such as shopping, reading, and finding direction (Anderson, 2016; Smith \& Anderson, 2016; Zickuhr \& Raine, 2014). The use of computers, mobile devices, and the internet are at the highest level to date and are expected to continue to increase because technology is becoming more accessible, especially for users in developing countries (Poushter, 2016). 


\section{CONCLUSION}

The study has some conclusions that (1) Most students state "Disagree" if the reading objectives are only: (a) to fulfill obligations, (b) merely hobbies, (c) spend time, but most students state "Agree" to: (a) discuss book with other people and (b) obtain the required information. (2) Students come from countries with above average of the OECD, most state "Agree" if the reading objective are to: (a) fulfill obligations, (b) channel hobbies, (c) discuss books with other people, (d) spending time, and (e) obtaining the information needed. While students come from countries with below average the OECD, most state "Agree" if the reading objective are to: (a) hobbies, (b) discuss books with others, and (c) get the necessary information, but most students state "Disagree" to: (a) fulfill obligations and (b) spend time.

Based on the results of variance analysis, there are differences in the perceptions of students both women and men towards all reading objective between the countries with above and below the average score of the OECD. Indonesian students have a common sequence of reading objective (hobbies or favorites, discussing other people's books, spending time, and when searching for the information needed, and because of obligations at school). The reliability of Indonesian students is 0.36 while the international data is 0.51 . Although both are low, the reliability of Indonesian students is still lower.

\subsection{Suggestions}

The study has some suggestions are as follows. First, teachers should be familiar with reading independence with students, and provided with problem solving strategies in reading. Second, teachers should reflect the benefits of reading in everyday life. Third, parents should teach their children to start reading from an early age and should provide reading material. Forth, government should introduce reading literacy of the PISA Test model for students at school.

\section{ACKNOWLEDGMENT}

The authors would like to thank the OECD for releasing PISA data every period for which the data used for this study. In addition, the authors would like to thank colleagues at the Center for Assessment and Learning, Agency of Research and Development, Ministry of Education and Culture who have provided input, suggestions, and comments in order to be contributive article.

Note: Safari is main contributor of the study in research method and discussions.

\section{REFERENCES}

Abidin, Z., 2017. Meningkatkan Keterampilan Membaca Siswa Kelas XI IPA 6 melalui Metode SQ3R SMA Negeri 1 Bontonompo, Kecamatan Bontonompo, Kabupaten Gowa. Jurnal Nalar Pendidikan, 5(1), hal. 55-63.

Ahmadi, M. R., \& Pourhosein Gilakjani, A., 2012. Reciprocal Teaching Strategies and Their Impacts on English Reading Comprehension. Theory and Practice in Language Studies, 2(10), 2053-2060.

Anderson, M. (2016). More Americans using smartphones for getting directions, streaming TV. Washington, D.C.: Pew Research Center. Retrieved from http://www.pewresearch.org/fact-tank/2016/01/29/us-smartphone-use/.

Brantmeier, C., 2005. Effects of readers' knowledge, text type and test type on L1 and L2 reading comprehension in Spanish. The Modern Language Journal, 8 (9), 37-53. https://doi.org/10.1111/j.0026-7902.2005. 00264.x

Carrell, P. L., 1989. Metacognitive Awareness and Second Language Reading. Modern Language Journal, 73, $120-133$.

Denton, C. A., Wolters, C. A., York, M. J., Swanson, E., Kulez, P. A, \& Francis, D. J. (2015)., Adolescents' use of reading comprehension strategies: Differences related to reading proficiency, grade level, and gender. Learning and Individual Differences, 37, 81-95. DOI: 10.1016/j.lindif.2014.11.016.

Dollah, W. A. K. W., Fakeh, S. S. K.W, Kamal Rafedzi, E. R., Ibrahim, A., Rahim, H., Masron, M. Z. A \& Ibrahim, M. R. (2017). Inculcating reading habits among secondary school students. Journal of Scientific and Engineering Research, JSAER, Pageno: 407, vol: 4, issues: 8 
Fergusson, D.M. \& Horwood, L.J. (1997). Gender differences in educational achievement in a New Zealand birth cohort. New Zealand Journal of Educational Studies 32(1), 83 -96.Köymen, B., \& Tomasello, M. (2018). Children's meta-talk in their collaborative decision making with peers. Journal of Experimental Child Psychology, 166, 549-566. https://doi.org/10.1016/j.jecp.2017.09.018

Grabe, W., 2004. Research on the teaching reading. Annual Review of Applied Linguistics, 24(5), 44-69. https://doi.org/10.1017/S0267190504000030.

Grabe, W., 2009. Reading in a second language: Moving from theory to practice. Cambridge University Press.

Guay, F., Chanal, J., Ratelle, C. F., Marsh, H. W., Larose, S., \& Boivin, M. (2010). Intrinsic, Identified, and Controlled Types of Motivation for School Subjects in Young Elementary School Children. British Journal of Educational Psychology, 80(4), 711-735.

Guria, A. (2019). PISA 2018: Insights and Interpretations, Andreas Schleicher. OECD.

Guthrie, J. T., \& Wigfield, A., 2000. Engagement and Motivation in Reading. In M. L. Kamil, P. B. Mosenthal, P. D. Pearson, and R. Barr (Eds.), Handbook of Reading Research. (Vol. III, pp. 403-22). Mahwah, NJ: Lawrence Erlbaum Associates.

Igbudu, U. (2015). Influence of gender on student academic achievement of government subject in public secondary schools in Oredo Local Government of Edo State, Nigeria. Journal of Educational and Social Research 5(2), 2015. Doi: 10.5901/jesr. 2015.v5n2p101.

Joseph, B.O., 2020. Evaluating Reading Habit among Junior Secondary School Students in Ekiti State in Nigeria. IJOLE: International Journal of Language Education, Vol. 4, No. 1, 2020. ISSN (Print) 2548-8457, ISSN (Online) $2548-8465$

Mangen, A.; Walgermo, BR.; and Bronnick, KK., 2020. Reading Linear Texts on Paper versus Computer Screen: Effects on Reading Comprehension. International Journal of Educational Research, 58:61-68. December 2013 with 28,670 Reads, DOI: 10.1016/j.ijer.2012.12.002

Mayes, D. K., Sims, V. K., \& Koonce, J. M., 2001. Comprehension and workload differences for VDT and paper-based reading. International Journal of Industrial Ergonomics, 28, 367-378.

Muter, P., Latremouille, S. A., Treurniet, W. C. \& Beam, P., 1982. Extended reading of continuous text on television screens. Human Factors, 24 (5), 501-508.

Nasri, M., \& Namaziandost, E., 2019. The impact of topic choice on descriptive writing ability among Iranian advanced EFL learners. International Journal of English Language Studies (IJELS), 1(1), 1-9. http://ijels.one/wpcontent/uploads/2019/11/The-Impact-of-TopicChoice-on-Descriptive-Writing-Ability-AmongIranianAdvanced-EFL-Learners-converted.pdf.

Owusu-Acheaw, M., \& Larson, A. G. (2014). Reading habits among students and its effect on academic performance: a study of students of Koforidua polytechnic. Library Philosophy and Practice, 0_1.

Pachtman, A. B., \& Wilson, K. A., 2006. What Do the Kids Think? The Reading Teacher, 59(7), 680-684.

Par, L., 2020. The Relationship between Reading Strategies and Reading Achievement of the EFL Students. International Journal of Instruction, 13(2), 223-238. https://doi.org/10.29333/iji.2020.13216a.

Putra, W.A.P, Purwadi, A.J., Wulandari, C., 2017. Pembelajaran Keterampilan Membaca di Kelas VII B SMP Negeri 9 Kota Bengkulu Tahun Ajaran 2016/2017. Jurnal Ilmiah Korpus, 1(II), hal. 233-247.

Reardon, S.F., Fahle, E.M., Kalogrides, D., Podolsky, A., \& Zarate, R.C. (2018). Gender achievement gaps in U.S School Districts (CEPA working paper No. 18-13). Retrieved from Stanford Centre for Education Policy Analysis http://cepa.stanford.edu/wp18-13.

Rohman, S., 2017. Membangun Budaya Membaca Pada Anak Melalui Program Gerakan Literasi Sekolah. TERAMPIL Jurnal Pendidikan dan Pembelajaran Dasar, Volume 4 Nomor 1 Juni 2017 p-ISSN 2355-1925 e-ISSN 2580-8915.

Sindik, J. (2011). Gender differences in the use of learning strategies in adult foreign language learners. Metodicki Obzoni 6(1), 2011. Doi:10.32728/mo.06.1.2011.01.

Smith, A., \& Anderson, M., 2016. Online Shopping and E-Commerce. Washington, D.C.: Pew Research Center Retrieved from http://www.pewinternet.org/2016/12/19/online-shopping-and-e-commerce/.

Stanovich, K. E., 1980. Toward an Interactive-Compensatory Model of Individual Differences in the Development of Reading Fluency. Reading Research Quarterly, 16(1), 32-71.

Talwiasih, S., 2019. Peningkatan Keterampilan Membaca Permulaan melalui Media Big Book SD Negeri 2 Karangsoko Kecamatan Trenggalek. Jurnal Pendidikan: Riset dan Konseptual, 3(1), hal. 61-64.

Tosepu, YA. (2018). Membaca yang Menjadikan Buku Bermanfaat. http://yusrintosepu.wixsite.com/yoes/singlepost/2018/10/10/Membaca-yang-Membuat-Buku-Bermanfaat.

Zickuhr, K., \& Raine, L. (2014). E-reading rises as device ownership jumps. Washington, D.C.: Pew Research Center Retrieved from http://www.pewinternet.org/2014/01/16/e-reading-rises-as-device-ownership-jumps/. 